\title{
KONSTRUKSI IDENTITAS KOMUNIKASI PEMASARAN PARIWISATA HALAL ACEH
}

\author{
Ade Muana Husniati ${ }^{1)}$, Maryam ${ }^{2)}$ \\ ${ }^{1)}$ Program Studi Ilmu Komunikasi, Universitas Malikussaleh \\ email: ademuana@unimal.ac.id \\ ${ }^{2)}$ Program Studi Administrasi Publik, Universitas Malikussaleh
}

\begin{abstract}
ABSTRAK
Penelitian ini mengkaji tentang bagaimana identitas komunikasi pariwisata halal Aceh yang mulai diperkenalkan kepada publik sejak tahun 2016 dikonstruksikan oleh Dinas Kebudayaan dan Pariwisata Aceh beserta tim pariwisata halal Aceh yang terdiri dari banyak elemen baik swasta, akademisi maupun pemerintahan Aceh itu sendiri. Brand pariwisata Aceh ini mengusung tema Islam yang Rahmatan Lil'alamin (rahmat bagi semesta alam) sebagai semangat bersama untuk memajukan industri pariwisata Aceh, sebagai cahaya benderang yang mengajak pada nilai-nilai kebaikan, kemakmuran, dan memberikan manfaat serta kebaikan bagi semua pihak yang tercermin melalui program-program pariwisatanya. Semangat dalam membentuk identitas pariwisata Aceh dengan tagline the light of Aceh atau Cahaya Aceh secara perlahan ingin merubah pandangan publik terhadap citra buruk syariah yang digambarkan oleh media selama ini yang dikemas dalam sebuah branding baru "the light of Aceh". Penelitian dengan paradigma konstruktivisme ini menjadikan pihak internal Dinas Kebudayaan dan Pariwisata Aceh beserta tim publikasi, tim pariwisata halal dan stakeholders eksternal lainnya yang ada di industri pariwisata Aceh sebagai informan. Hasil penelitian menunjukkan bahwa upaya yang dijalankan oleh Disbudpar Aceh dalam mengkonstruksi destinasi wisata halal aceh dengan memanfaatkan social media terutama Instagram sangat kekinian dan tepat sasaran, disamping penggunaan media lainnya serta dibantu dengan bentuk komunikasi tatap muka. Hal ini tampak pada beberapa prestasi yang diperoleh baik pada tingkat nasional, maupun internasional atas upaya yang telah dilakukan tersebut.
\end{abstract}

Kata kunci: Komunikasi Pariwisata, Pariwisata Aceh, Pariwisata Halal

\section{PENDAHULUAN}

Aceh pada tahun 2016 oleh Kementerian Pariwisata dijadikan sebagai salah satu daerah tujuan wisata halal di Indonesia bersama dengan Nusa Tenggara Barat dan Sumatera Barat. Tentu saja hal ini mendorong Acehuntuk turut serta mengejar pasar wisatawan halal dunia. Salah satunya pada tahun yang sama pariwisata Aceh membangun brand sekaligus citra sebagai daerah yang layak 
untuk dijadikan prioritas sebagai destinasi pariwisata halal dan memukau untuk dijadikan tempat berinvestasi. Otonomi daerah merupakan salah satu contoh ketika pemerintah lebih mengarah pada fungsi koordinasi ketimbang ikut campur terlalu jauh hingga malah menghambat perkembangan daerah. Otonomi daerah juga memberi kesempatan untuk tiap daerah membentuk citranya masing-masing. Tentu akan sangat luas sekali ketika melihat bagaimana Indonesia mengelola citranya. Maka dalam artikel ini, yang menjadi fokus adalah konstruksi identitas pariwisata halal Aceh. Yakni bagaimana Aceh, membangun dan mengelola citranya melalui sektor pariwisata.

Syariah Islam telah menjadi payung hukum dalam setiap kebijakan di Aceh. Sebagaimana kita ketahui, Aceh memiliki Qanun (peraturan perundangundangan sejenis Peraturan Daerah) yang mengatur penyelenggaraan pemerintahan hingga kehidupan bermasyarakat Kemudian, Wilayatul hisbah atau polisi syariahlah yang bertugas untuk mengawasi pelaksanaan syariah Islam di Aceh. Melihat aturan-aturan berbasis syariah yang meliputi bidang aqidah, syar'iah, akhlak yang sudah berlangsung belasan tahun secara terlembaga, tentu juga mempengaruhi perilaku masyarakat ketika berinteraksi dan berada di ruang publik. Hal ini pulalah kemudian dijadikan semangat dalam membentuk identitas pariwisata Aceh dengan tagline the light of Aceh yang pada Juni 2016 diperkenalkan kepada publik. Mungkin, secara perlahan melalui brand pariwisata ini Aceh ingin merubah pandangan publik terhadap citra buruk syariah yang digambarkan oleh media. Pariwisata Aceh telah dikemas dalam sebuah branding baru,"The Light of Aceh". Cahaya Aceh ini merefleksikan semangat bagi seluruh masyarakat yang disatukan melalui Syariat Islam yang Rahmatan lil 'alamiin, sebagai cahaya benderang yang mengajak pada nilai-nilai kebaikan, kemakmuran, dan memberikan manfaat serta kebaikan bagi semua pihak. Beberapa poin dalam membentuk positioning Aceh melalui brand the light of Aceh seperti yang tertuang dari laman Disbudpar Aceh yakni, di bidang pariwisata, Aceh mempertegas posisinya sebagai destinasi wisata halal di Indonesia.

Wisata dan gaya hidup halal telah menjadi trend global, wisatawan nonmuslim juga dapat menikmati jenis wisata ini. Sebagai negeri yang semua sendi 
kehidupan berlandaskan syariat Islam, termasuk pariwisata, Aceh memiliki akar yang kuat untuk membentuk branding mewujudkan destinasi wisata halal. Kementerian Pariwisata RI tahun 2016 menominasikan Aceh sebagai salah satu destinasi wisata halal dunia. Sebagai daerah yang punya potensi besar di bidang pariwisata, pemerintah Aceh menjadikan pariwisata sebagai sektor utama pasca era minyak dan gas, sehingga dapat menggeliatkan roda ekonomi masyarakat. Wisata halal saat ini menjadi sorotan dunia. Negara-negara yang tidak berpenduduk mayoritas muslimpun saat ini sedang menyasar pasar wisata halal. Alangkah disayangkan apabila Aceh yang selama ini telah menjalankan qanun syariah tidak memanfaatkan peluang yang telah dibentuk oleh pasar dunia.

\section{LANDASAN TEORI}

\section{Konstruksi Sosial Media Massa}

Konstruksi Sosial Media Massa berawal dari pemikiran sosiolog Peter Ludwig Berger dan Thomas Luckmann pada tahun 1966 dalam karyanya The Social Construction of Reality: A Treatise in the Sociology of Knowledge. Sebenarnya teori ini mengemukakan asumsi Berger tentang hubungan diantara individu dan masyarakat berdasarkan tinjauan sosiologi pengetahuan. Melalui penelitian Burhan Bungin yang berjudul "konstruksi sosial media massa: realitas iklan televisi dalam masyarakat kapitalistis pada tahun 2000, teori dan pendekatan konstruksi sosial atas realitas Peter L. Berger dan Thomas Luckmann telah direvisi dengan melihat variabel atau fenomena media massa menjadi sangat substansi dalam proses eksternalisasi, subyektivasi, dan internalisasi. Dengan demikian, sifat dan kelebihan media massa telah memperbaiki kelemahan proses konstruksi sosial atas realitas yang berjalan lambat itu. Substansi "teori konstruksi sosial media massa" adalah pada sirkulasi informasi yang cepat dan luas sehingga konstruksi sosial berlangsung dengan sangat cepat dan sebarannya merata. Realitas yang terkonstruksi itu juga membentuk opini massa. Posisi konstruksi sosial media massa adalah mengoreksi substansi kelemahan dan melengkapi konstruksi sosial atas realitas Berger dan Luckmann, dengan menempatkan seluruh kelebihan media massa dan efek media pada keunggulan konstruksi sosial 
media massa atas konstruksi sosial atas realitas. Berikut gambar proses konstruksi sosial media massa oleh Burhan Bungin (2008:195):

Konten konstruksi sosial media massa, dan proses kelahiran konstruksi sosial media massa melalui tahapan sebagai berikut:

1.Tahap menyiapkan materi konstruksi

2.Tahap sebaran konstruksi

3.Tahap pembentukan konstruksi realitas

4.Tahap konfirmasi

\section{Komunikasi Pemasaran}

Komunikasi pemasaran merupakan penggabungan konsep-konsep komunikasi dan pemasaran. Secara sederhana komunikasi siartikan sebagai sebuah proses pengiriman dan penerimaan pesan. Sementara pemasaran secara sederhana disefinisikan sebagai sebuah proses untuk menemukan dan memenuhi kebutuhan pelanggan. Maka penggabungan keduanya menjadi sebuah proses pengiriman dan penerimaan pesan-pesan terkait kebutuhan pelanggan. Pendapat lain mengemukakan bahwa komunikasi pemasaran tidak hanya menemukan dan memenuhi kebutuhan pelanggan, tetapi komunikasi pemasaran mampu menciptakan kebutuhan baru yang sebenarnya tidak benar-benar dibutuhkan oleh pelanggan. Sementara Schiffman dan Kanuk (2004) dalam Suryana (2019:1.6) menyebutkan bahwa pada umumnya komunikasi pemasaran yang dilakukan perusahaan dirancang agar konsumen mengetahui adanya produk tersebut, mendorong adanya pembelian atau komitmen, menimbulkan sikap positif terhadap produk, memberikan arti simbolis terhadap produk, atau menunjukkan bagaimana komunikasi tersebut dapat lebih baik dalam memecahkan masalah konsumen jika dibandingkan dengan produk (barang atau jasa) kompetitor.

\section{Place Branding}

Place Branding merupakan sebuah bentuk komunikasi pemasaran berkaitan dengan membangun identitas ataupun citra sebuah tempat. Terkait dengan brand sebuah tempat tujuan, Anholt dalam Koswara (2013:340) menyebutkan: 
"Place branding is the management of place image through strategic innovation and coordinated economic, commercial, social, cultural, and government policy. Competitive identity (CI) is the term to describe the synthesis of brand management with public diplomacy and with trade, investments, tourism and export promotion"

Pengelolaan brand sebuah tempat tujuan merupakan rangkaian upaya pembentukan identitas merk yang kemudian dilanjutkan dengan upaya memposisikan merek dalam benak pengunjung, dan akhirnya terbentuk menjadi citra merek sebuah tempat tujuan. Baik atau buruknya pengunjung atau stakeholder (pemangku kepentingan) lainnya mencitrakan sebuah tempat akan bergantung kepada upaya terkoordinasi dalam masalah-masalah yang menyangkut internal sebuah kota dan negara, sehingga memberikan nilai keuntungan kompetitif dengan kota lainnya. Beberapa keuntungan penggunaan brand dalam mempromosikan sebuah tempat antara lain adalah Pertama, kota dapat dijadikan sebagai sebuah hak cipta, yang artinya dapat mengingatkan orang tentang keunikan sebuah kota. Kedua, kota juga dapat menjadi sebuah simbol kualitas yang dapat meyakinkan pengunjung, kualitas yang dapat merepresentasikan kepribadian pengunjungnya yang ditunjukkan melalui tampilan-tampilan yang disampaikan oleh merek sebuah kota. Ketiga, ketika digunakan berkali-kali, merek menjadi sebuah metode tangan pendek untuk mengingatkan pengunjung potensial mengenai manfaat yang ditawarkan oleh sebuah kota.

langkah selanjutnya dalam proses pemasaran adalah perencanaan promosi. Perencanaan promosi akan dirancang untuk mengkomunikasikannya kepada target segmen mengenai citra kota dan manfaat-manfaat yang disediakan dengan mengunjungi sebuah kota. Akan lebih banyak komponen terlibat dalam mengembangkan sebuah strategi promosi dari pada sekedar meletakkan sebuah slogan cerdas dan brosur yang bagus. Promosi dapat dirancang untuk mempengaruhi secara rasional informasi-informasi yang faktual yang dibutuhkan pengunjung potensial dalam proses pengambilan keputusannya untuk mengunjungi sebuah tempat. Promosi juga dapat dirancang melalui penggunaan pesan-pesan persuasif yang menarik perhatian turis potensial. Jika sebuah pendekatan pesan rasional dan emosional telah dirancang, pesan-pesan promosi 
kota harus menarik perhatian konsumen dengan sejumlah pesan-pesan lainnya. Komunikasi merek terpadu menjadi sebuah harga mutlak apabila pesan-pesan kota ingin diterima secara utuh oleh konsumen.

\section{METODE PENELITIAN}

Paradigma penelitian ini adalah paradigma Constructivism, dimana paradigma Constructivism dimulai dengan pertanyaan mendasar yaitu bagaimana orang-orang disuatu tempat/lokasi mengkonstruksikan realita. Paradigma ini membahas mengenai persepsi mereka, "kebenaran", penjelasan, kepercayaan dan pandangan mengenai dunia. Selain itu konsekuensi dari konstruksi tersebut bagi perilaku mereka dan orang-orang lain yang berinteraksi dengan mereka juga diteliti (Patton, 2002:96). Paradigma konstruktivisme dalam penelitian ini menjadi acuan bagi peneliti dalam mengkonstruksi realita di Aceh terkait konstruksi citra destinasi wisata halal beserta segala unsur yang mendukung proses lahirnya. Bagaimana ia dipersepsi dan diciptakan hingga akhirnya dipercaya sebagai sebuah kebenaran. Penelitian kualitatif ini menjadikan tim publikasi dari Dinas Kebudayaan dan Pariwisata Aceh

\section{HASIL DAN PEMBAHASAN}

\section{Mengonsep Ulang Definisi Halal}

Menurut tim publikasi Dinas Kebudayaan dan Pariwisata Aceh, halal itu bukan hanya labelisasi untuk makanan saja, tetapi lebih luas dari itu. Meliputi berbagai proses dari barang yang akan digunakan, dikonsumsi, hospitality beserta seluruh elemen yang terlibat dalam industri pariwisata hingga perilaku seluruh unsur dalam masyarakat Aceh. Meski Aceh sudah "default” halal, artinya sudah identik dengan Islam, namun dalam pengembangan industri pariwisata, citra saja tidak cukup tanpa mengikuti prosedur yang terlegitimasi atau dapat dibuktikan secara formal administratif, mengikuti standar yang telah ditetapkan oleh pihak yang memiliki kewenangan, yakni, Kementerian Pariwisata (Kemenpar) yang bekerjasama dengan Majelis Ulama Indonesia (MUI). Sebagaimana hasil wawancara dengan Tim Publikasi Disbudpar Aceh sebagai berikut: 
"Itu yang selalu diwanti-wanti ..., jangan gara-gara kita ni Indonesia ya, terlebih di Aceh, jangan gara-gara kita membawa di defaultnya Halal. Aceh itu dari syariat islam udah halal gitu tapi bukan itu tu, perilaku tukang becak, taksi dibandara itu halal gak sih? Menyapa gak sih, halal itu kan lebih ke perilaku hospitality nya, mushala ditempat wisata itu ada gak? Kamar mandinya bersih atau enggak sampe kesitunya, karena biasa orang tandai halal itu identik dengan makanan, kalo ditempel o gak halal, makanya sekarang festival kuliner nanti ada pos sertifikasi halal dari MPU. Jadi semua rumah makan, hotel, itu ada proses halal, ada di tempel logo bukan ada kepentingan masyarakat lokal tapi ketika ada datang wisatawan emang datang dari Malaysia, Brunei, hotel halal. Hotel halal maksudnya apa contohnya ada mukena, gak harus kita tanyak telpon susah-susah ini mukenanya mana, sajadahnya mana, enggak."

Sertifikat halal tidak hanya untuk restoran atau penyedia produk kuliner saja. Tetapi juga ditujukan untuk hotel yang tidak hanya mensyaratkan tamu yang boleh menginap di kamar yang sama adalah pasangan yang halal, akan tetapi, proses ketersediaan air yang digunakan untuk segala operasional hotel haruslah melalui proses yang halal. Artinya, proses dari pengambilan, penyaringan, hingga digunakan, semuanya harus mendapatkan sertifikasi halal dari mulai restoran, spa, hingga kolam renang.

Demikian pula halal menurut kabid pemasaran disbudpar Aceh mengenai halal yang bukan seperti yang dibayangkan secara umum oleh masyarakat luas yakni hanya terkait makanan yang mengandung anjing ataupun babi saja. Tetapi juga meliputi kesadaran masyarakat untuk melahirkan budaya sertifikasi terhadap program, potensi, usaha, budaya bersih dan higienis serta pelayanan yang baik yang dapat langsung dirasakan oleh wisatawan dan kelengkapan sarana dan prasarana ibadah di berbagai tempat mulai dari warung kopi hingga ke tempattempat yang ramai dikunjungi lainnya.

Kabid Pemasaran juga mengkritisi perilaku masyarakat yang dianggap masih memerlukan proses untuk memahami konsep halal tersebut. Selama ini masyarakat dianggap cukup puas dengan label halal yang disebut "default" oleh tim publikasi. Namun kenyataannya, banyak perilaku yang dianggap sepele 
ternyata belum mencerminkan perilaku halal yang sesuai dengan stardar sertifikasi.

Istilah wisata halal sendiri baru dipopulerkan di Aceh sekitar tahun 2016 seiring dengan peluncuran brand baru. Sebelumnya istilah yang sering didengar adalah wisata reliji dan wisata Syariah yang dalam Qanun Aceh no 08 tahun 2013 (tentang kepariwisataan) pasal 13 ayat 1 huruf a sendiri disebutkan bahwa jasa wisata syariat adalah jasa wisata tarikat dan zikir, atraksi seni sufistik, pengobatan tradisional, dan wisata syariat islam lainnya. tentu saja secara tekstual makna dalam Qanun syariat tersebut lebih sempit dibandingkan dengan makna penggunaan istilah halal yang disebutkan oleh tim publikasi, kabid pemasaran dan ketua ASPPI Aceh. Berikut hasil wawancara dengan kabid pemasaran:

"Qanun sudah ada, UU No 08 tahun 2013. Belum (yang khusus tentang pariwisata halal Aceh), tapi lagi coba kita buat dalam bentuk pergubnya. Kita coba fokus pada wisata halal..."

Media massa pernah memberitakan beberapa kasus penutupan tempat rekreasi (pantai) karena dianggap melanggar Syariah. Hingga berdampak pada citra Aceh yang dianggap kaku dan keras oleh masyarakat luar Aceh baik domestik maupun internasional. Kepala bidang pemasaran Disbudpar Aceh sendiri menyampaikan bahwa yang perlu dilakukan saat ini adalah membenahi cara sumberdaya manusianya terlebih dahulu, aturannya, aparaturnya juga masyarakatnya. Apabila budaya halal sudah terbentuk, maka biasanya hal-hal lain akan ikut dengan sendirinya. Untuk mewujudkan itu semua, dibutuhkan kerjasama seluruh elemen yang ada di Aceh.

Sebelum lahir istilah wisata halal yang kini menjadi tren dunia, istilah lain yang juga pernah digunakan adalah muslim friendly destination (destinasi ramah terhadap muslim) pada saat Jero Wacik menjabat sebagai Menteri Kebudayaan dan Pariwisata (2004-2009). Persyaratan untuk menjadi destinasi wisata muslim saat itu bukan berarti untuk wilayah dengan penduduk muslim. Namun yang menjadi persyaratan adalah bagaimana sebuah wilayah tersebut mampu menciptakan kenyamanan bagi wisatawan baik dari sisi kebersihan, pelayanan, kejujuran, keikhlasan. 
Kabid pemasaran juga menambahkan bahwa penyampaian informasi yang baik dan benar menjadi tanggung jawab seluruh elemen masyarakat Aceh. Aceh terus membenahi dan mempersiapkan diri agar benar-benar layak menjadi destinasi wisata halal dunia.

Asosiasi Pelaku Pariwisata Indonesia (ASPPI) Aceh yang diketuai oleh Dedy T. Zaimy menyatakan bahwa untuk percepatan Aceh sebagai destinasi wisata halal, asosiasi ini dilibatkan oleh pemerintah Aceh. Sekitar 90\% anggota ASPPI menjadi bagian dari kelompok kerja (pokja) yang dibentuk. Antara lain pokja restoran halal, pokja biro perjalanan halal dan pokja hotel halal. Mereka membantu Disbudpar Aceh untuk mensosialisasikan sertifikasi halal bagi industri yang terlibat pada sektor pariwisata di Aceh. Untuk restoran dan biro perjalanan cenderung mudah mengikuti proses sertifikasi halal. Namun untuk hotel, masih terdapat banyak tantangannya dan prosesnya lebih Panjang dengan standarisasi yang sudah disiapkan oleh Majelis Permusyawaratan Ulama (MPU) Aceh. Hal ini semakin menguatkan pernyataan Kabid Pemasaran Disbudpar Aceh dan tim Publikasi sendiri mengenai halal yang tidak hanya sebatas pada makanan saja. Bahwa ada semacam perluasan makna dari kata halal yang mencerminkan keseluruhan budaya dan perilaku yang penuh rasa tanggung jawab.

\section{TAHAP MENYIAPKAN MATERI KONSTRUKSI}

\section{a. Tim Publikasi}

Tahap menyiapkan materi konstruksi dilakukan oleh pihak Dinas Kebudayaan dan Pariwisata Aceh melalui tim publikasi. Tim ini ditunjuk melalui SK dan mereka terdiri atas komunitas pariwisata. Tim ini sendiri terdiri atas fotografer, content creator dan mereka juga membantu Disbudpar Aceh untuk merangkul beragam komunitas yang terkait dengan pariwisata Aceh lainnya. Seperti Genpi Aceh, para blogger, fotografer dan lain sebagainya. Seperti yang disampaikan oleh Kepala Bidang Pemasaran Disbudpar Aceh bapak Ramadhani Sulaiman pada tanggal 10 Agustus 2017 sebagai berikut: "kita punya Tim publikasi yang kita rekrut". Menurut tim publikasi yang di koordinir oleh Aulia, tim ini terdiri dari 10 orang dengan beragam fungsi sebagai berikut:

70 
"Itu mulai dari tim kreatif, photographer, videographer, tim admin, admin website ada 10 orang, ada tim admin untuk web 2 orang, terus photographer 1 orang, videographer 1 orang, tim liputan lapangan 2 orang" (11 Agustus 2017)Ada karena setiap ada kegiatan misalnya memang ada pak kadis, ada ni bidang-bidangnya, itu kita yang mengcover untuk turun ke lokasi, maksudnya untuk update, live twit, live twit yang apa namanya, seluruh rangkaian kegiatan kita twit, twit di twitter. Dari 2 orang yang di tim ini yang biasanya untuk mengcover itu, baru tim ini nanti yang ekspor ke tim kreatif konten untuk membuat berita atau release, jadi totalnya 10 orang”.

Untuk kekurangan tenaga apabila agenda kegiatan pariwisata di Aceh sangat banyak, tim ini merekrut tenaga relawan (volunteer) untuk membantu menjangkau setiap arena kegiatan dan meliputnya. Anggota tim yang bertindak sebagai administrator (admin) tidak diganggu dan harus tetap berada di tempat. Karena fungsinya mengkoordinir setiap kegiatan dan mempublikasikannya melalui sosial media. Selain menangani hal-hal terkait publikasi, tim ini juga berperan sebagai event organizer untuk beberapa agenda kegiatan sesuai dengan permintaan. Seperti yang pernah dilakukan di Sabang, mereka mempublikasikan kegiatan yang diadakan secara mendadak namun melakukan promosi dengan maksimal selama beberapa hari seperti promosi melalui stasiun radio setempat hingga roadshow ke sekolah-sekolah. Berdasarkan pengalaman yang sudah dilalui oleh tim ini, mereka menjadi lebih mampu memetakan dan memahami kondisi lapangan (khalayak, antusiame masyarakat masing-masing daerah) untuk sebuah agenda terkait pariwisata.

Proses mempersiapkan materi konstruksi dilakukan oleh tim publikasi yang terdiri dari sepuluh anak muda professional dalam bidangnya masingmasing. Yakni sebagai photographer, content creator, videographer, admin, serta terkadang mereka juga merangkap sebagai panitia maupun event organizer. Tim ini sangat berperan penting dalam proses menyiapkan materi konstruksi hingga dapat diterima oleh para pengguna Instagram. Tim ini juga sangat mengenal karakteristik khalayaknya. Baik khalayak social media hingga masyarakat suatu wilayah terkait agenda kepariwisataan. Sementara untuk kontennya, menurut 
kepala bidang pemasaran yang menjadi materi postingan pada social media adalah kegiatan-kegiatan yang bersifat atraktif, memiliki daya tarik, punya karakteristik dan berbentuk event serta memperlihatkan keindahan alam atau potensi daerah.

\section{b. Branding Pariwisata Halal Aceh "The light of Aceh"}

Sebagaimana kita ketahui bahwa branding merupakan sebuah proses dari menciptakan hingga mempertahankan brand di benak publik yang tidak hanya sekedar logo, nama dan permainan warna serta desain. Dalam proses branding tersebut, Aceh melahirkan sebuah brand pariwisata semenjak tahun 2016 dengan tagline the light of Aceh untuk mensupport kemenangan Aceh pada kompetisi pariwisata halal nasional di tahun yang sama yang diumumkan pada tanggal 21 september 2016. Pada kompetisi tersebut aceh memenangkan tiga kategori yaitu, airport ramah wisatawan muslim terbaik (Bandara Sultan Iskandar Muda, Banda Aceh), destinasi budaya ramah wisatawan muslim terbaik, dan daya Tarik wisata terbaik (Masjid Raya Baiturrahman, Banda Aceh).

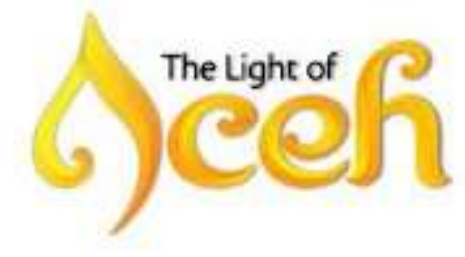

Gambar 1: brand pariwisata Aceh

Berikut wawancara dengan Kepala bidang Pemasaran Disbudpar Aceh terkait branding terbaru Pariwisata Aceh:

"Kalo tagline The Light of Aceh itu adalah branding pariwisata Aceh terbaru yang kita gali bersama melibatkan stakeholders terkait khususnya mereka dari akademis, mereka dari pemerintahan, kabupaten kota, termasuk para industri dan yang lebih menarik lagi kita juga merekrut konsultan dari jogja, ya artinya kita coba koordinasikan pemikiran mereka tidak hanya dari dalam tapi dari luar Aceh, artinya branding yang kita bangun tersebut adalah harus bisa menjadi teknik yang bisa diterima oleh semua pihak, menarik kemudian bisa memiliki waktu yang panjang."

Brand baru pariwisata Aceh lahir dengan melibatkan banyak pihak yang dianggap mampu dan mewakili elemen-elemen yang terlibat dalam sector 
pariwisata seperti akademisi, pemerintahan kabupaten dan kota yang ada di Aceh, para pekerja industri serta konsultan swasta. Melalui seminar, focus group discussion (FGD), rapat, diskusi, presentasi serta adanya kepanitiaan terkait penciptaan brand baru tersebut. Berikut wawancara dengan Kabid Pemasaran:

"Iya seminar, focus group discussion, FGD, rapat-rapat, diskusi, presentasi, dan semua ada. Konsultannya itu ada 2 yaitu mas Ari dengan mas satu lagi siapa namanya saya lupa, mereka itu dari Jogja, dan mereka itu adalah praktisi. Ada- ada, nanti saya kasi (nama perusahaan konsultannya). Itu bentuk dari pada semangat kita melihat begitu banyak potensi yang kita miliki dari konteks alam, budaya, manusia dan juga konteks keberpihakan pemerintah atau daerah wisata, dan kita juga melihat bagaimana hal baru, planning baru, itu media digital semakin merakyat sehingga kita melihat konsep pariwisata di Aceh ni harus kita re-design khususnya dengan tagline yang kita miliki dari Aceh Fantastic Destination menjadi The Light of Aceh atau Cahaya Aceh, nah disini kita bangga wawasan the light of Aceh, atau cahaya mampu mewarnai Aceh sebagai destinasi wisata.. kedepan. sebelumnya itu adalah Aceh Fantastic Destination. sekitar 3 atau 4 tahun, dari 2012 sampe 2016”"

Elemen grafis brand pariwisata aceh ini terdiri atas logo, tagline, nama, serta kombinasi warna yang penggunaannya disesuaikan dengan tempat dan kebutuhan, dengan desain sederhana namun penuh makna. Asal usul konsep dari brand berakar dari potensi Aceh sebagai provinsi syariah dan rahmatan lil alamin dipilih untuk mengkomunikasikan destination branding. Rahmatan diartikan sebagai rahmat, keberkahan, cahaya. Alamiin diartikan sebagai alam semesta, dunia. Rahmatan lil alamiin dimaknai sebagai cahaya bagi dunia. Dunia dalam hal ini difokuskan pada Aceh. Dengan tujuan untuk mewujudkan islam sebagai rahmatan lil alamiin yang dimulai dari provinsi Aceh. Menurut tim branding penggunaan tagline destination branding the light of Aceh dapat menjadi spirit atau semangat bagi seluruh warga, komunitas, birokrasi, akademis dan bisnis secara keseluruhan yang kaya warna keberagaman namun disatukan dengan syariat islam. Berikut gambar penjelasan oleh komunitas I Love Aceh: 


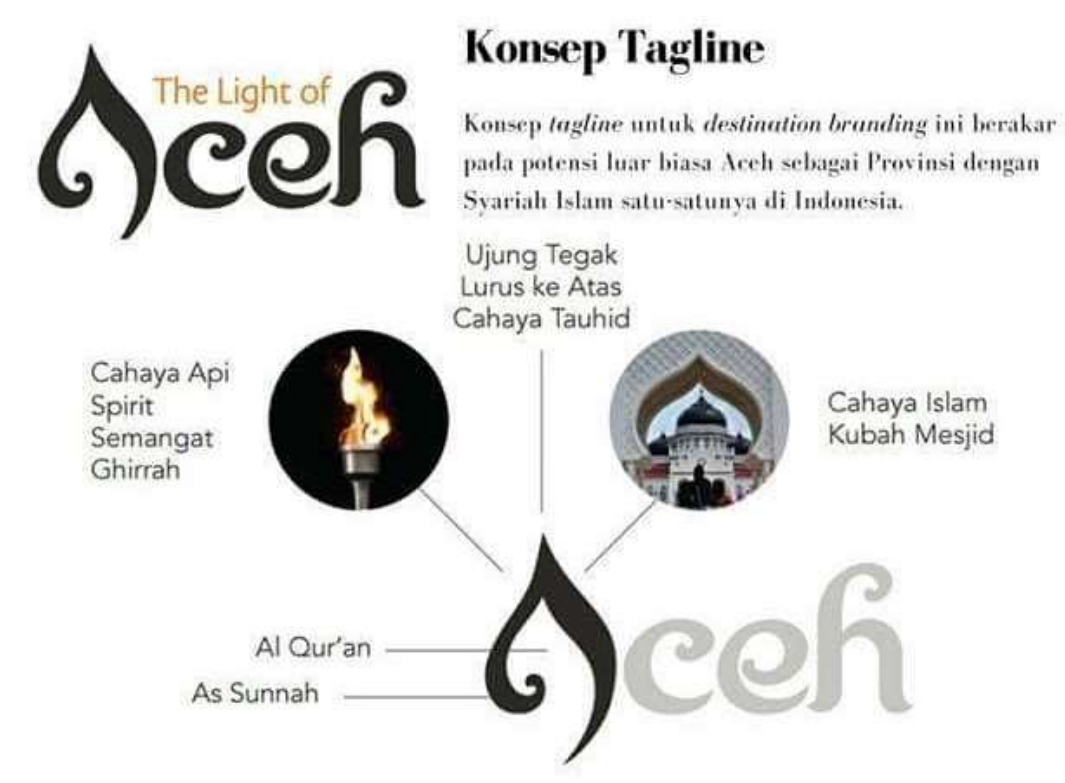

Gambar 2: brand (asal usul logo dan konsep tagline)

Logo the Light of Aceh yang menggunakan Bahasa Inggris tentu saja guna menarik minat wisatawan manca negara sebagai berikut:

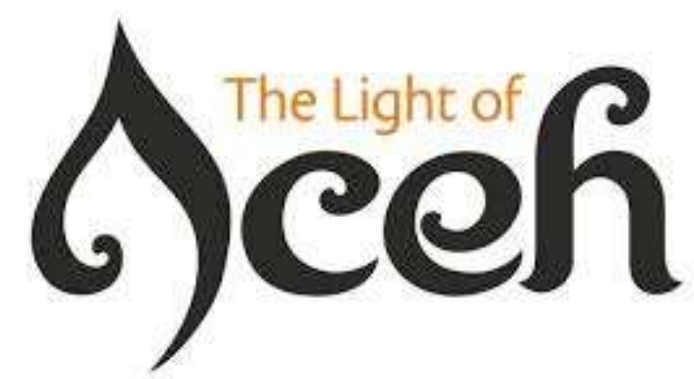

Gambar 3: Logo dengan tagline berbahasa Inggris

Selain mendesain logo berbahasa Inggris, logo dengan Bahasa Indonesia juga telah didesain untuk kepentingan penggunaan bagi pemasaran dengan jangkauan wisatawan domestik sebagai berkut: 


\section{C)eeh}

Gambar 4: Logo dengan tagline berbahasa Indonesia

Logo baru beserta tagline the light of Aceh ini baru di luncurkan pada pertengahan tahun 2016 tepatnya pada Juni 2016 sekaligus menyongsong kompetisi wisata halal nasional dan internasional.

Pesan dari the light of Aceh menurut Kabid Pemasaran Disbudpar Aceh adalah:

"pesan utamanya (the light of Aceh) sih sederhana, kita melihat provinsi Aceh, Aceh yang berbudaya, Aceh yang adat istiadatnya, Aceh dengan potensi wisata alamnya, Aceh potensi syari'at islam yang berkembang pesat kemudian Aceh dengan jumlah populasi islam yang besar dan disini kita ingin angkat karakteristik Aceh, bahwasanya Aceh itu sangat kental dengan budaya islamnya, jadi kita coba bangun dengan The Light of Aceh atau Cahaya Aceh dengan filosofinya dengan mengajak seluruh masyarakat...yang disatukan dalam syariat islam rahmatan lil alamin sebagai cahaya yang terang benderang, dan juga rahmat bagi semua pihak, tapi tidak mesti dibatasi islam tapi siapapun yang datang ke Aceh tu kita jadikan tamu kita dengan cahaya yang terang benderang mampu mewarnai semua kehidupan masyarakat."

Beberapa hal hal yang dianggap perlu menjadi perhatian dalam mengembangkan sebuah branding yakni durable, diterima oleh masyarakat, sesuai karakter daerah, mudah diingat, singkat, padat dan memiliki makna yang mendalam.

\section{TAHAP SEBARAN KONSTRUKSI}

\section{Penggunaan Social Media}

Media baru muncul sebagai hasil dari inovasi teknologi. Kepentingan yang makin besar dari perusahaan media terhadap komunikasi berbasis internet pada 
kenyataannya adalah cerminan dari bangkitnya bentuk baru komunikasi (McQuail, 2011). Informasi digital termasuk melalui media baru mempunyai karakteristik tersendiri. Yakni, manipulable, networkable, dense, compressible, dan impartial (Flew, 2008). Dalam pemasaran pariwisata penyertaan revolusi teknologi disebut sebagai online tourism marketing sebagai usaha untuk menjual produk/jasa pariwisata dan membangun hubungan dengan wisatawan menggunakan internet (Hasan, 2015).

Disbudpar Aceh selain menggunakan new media Instagram, juga menggunakan beberapa platform social media lainnya. Yaitu twitter, youtube, facebook serta website. Sebagai mana Instagram terdiri atas Instagram bisnis dan birokrasi, website juga terbagi atas dua kategori tersebut. Untuk bisnis beralamat www.acehtourism.travel sementara untuk birokrasi www.disbudpar.acehprov.go.id. Pendekatan publikasi meliputi empat elemen yang disebut POSE (Paid media, Owned media, Social Media, Endorser). Pendekatan ini pula yang digunakan oleh Kementerian Pariwisata Republik Indonesia

Meski promosi agenda pariwisata saat ini telah beralih pada penggunaan media kekinian (new media), namun disbudpar Aceh masih tetap menggunakan media massa lama agar hubungan baik tetap terjaga. Bagaimanapun, media massa lama masih mendapatkan tempat untuk beberapa kharakteristik yang dimilikinya, terutama tingkat kepercayaan hasil liputannya, ditengah banyaknya berita hoaks yang hilir mudik pada social media. Sebelumnya, media massa yang menjadi sarana promosi adalah media local dan nasional. Pengiriman rilis juga tergantung jumlah anggaran yang tersedia. Biasanya setahun tiga sampai empat release.

Disbudpar Aceh bila dilihat dari postingan pertamanya mulai menggunakan Instagram sebagai sarana promosi dimulai pada taggal 6 mei 2015 . Jumlah followers dan likes yang diberikan pada setiap postingan juga terus mengalami meningkat. Pada tanggal 20 november 2017, jumlah followers sebanyak 15,3K followers dan pada 3 juni 2018 meningkat menjadi 18,4K. pada tahun 2016 saat Aceh mulai memperkenalkan branding wisata barunya, serta mengejar penghargaan nasional dan internasional untuk pariwisata halal, ig 76 
@ disbudpar_aceh sangat gencar melakukan postingan sepanjang tahun hingga berjumlah 399 posts. Jumlah postingan ini merupakan jumlah postingan yang cukup besar selama setahun bagi ig @disbudpar_aceh menurut hasil pengamatan peneliti.

Postingan pertama akun ini berupa event pulau Weh Dive Fest "nature in paradise" June 6-7, 2015. Postingan ini hanya disukai oleh 33 followers dengan 7 komentar. Tema pariwisata yang digunakan masih Visit Aceh yang sudah digunakan sejak tahun 2013. Visit aceh mengusung tagline fantastic destination, sebelum akhirnya Aceh meluncurkan brand baru pada tahun 2016.

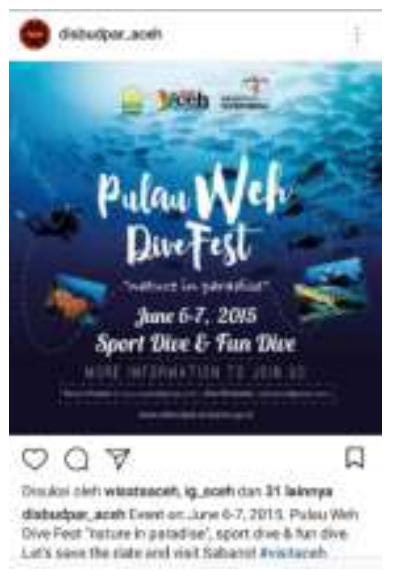

Gambar 5: Postingan pertama pada ig @ disbudpar_aceh

\section{TAHAP PEMBENTUKAN KONSTRUKSI REALITAS MELALUI INSTAGRAM}

\section{Penggunaan instagram oleh disbudpar Aceh}

Sejak peluncuran branding destinasi wisata Aceh yang baru pada pertengahan tahun 2016, promosipun lebih digencarkan pada ajakan untuk mendukung Aceh dan Indonesia memenangkan kompetisi pariwisata halal internasional yang diselenggarakan di Abu Dhabi. Beragam upaya kampanye lapangan dan postingan tersebut tidaklah sia-sia. 


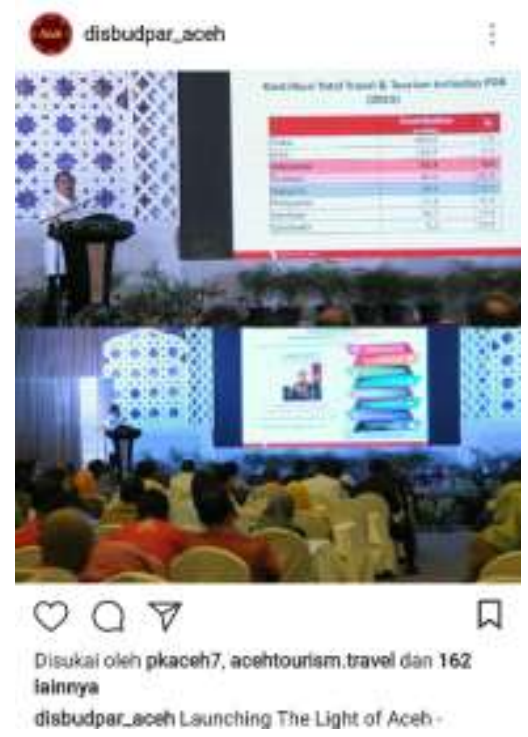

Gambar 6: launching the light of Aceh

Launching brand pariwisata Aceh ini dilakukan bersamaan dengan rapat koordinasi kebudayaan dan pariwisata aceh pada tanggal 19 september 2016. Namun soft launchingnya sudah dilakukan beberapa bulan sebelumnya dengan mengeluarkan video dan iklan radio juga dengan memperkenalkannya kepada komunitas pemuda yang aktif di bidang pariwisata dan social media.

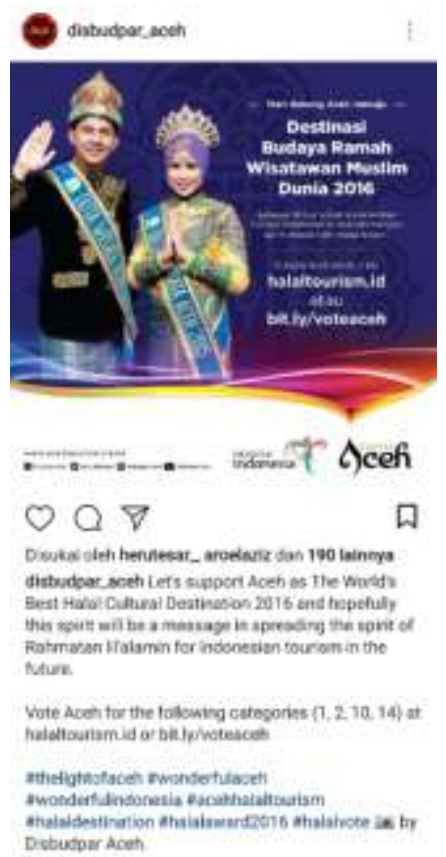

Gambar 7: ajakan untuk voting pada WHTA 
Setelah diluncurkannya brand pariwisata aceh yang baru, kampanye melalui Instagram untuk memenangkan Aceh pada ajang pariwisata internasionalpun kian gencar dilakukan. Dengan menayangkan video para artis dan public figure lainnya. Bukan hanya kampanye melalui Instagram, tim relawan juga melakukan kunjungan lagsung ke masyarakat dan mengajak masyarakat untuk berpartisipasi. Mulai dari warung kopi, berbagai pusat keramaian, mengisi acara talkshow di stasiun televisi lokal hingga ke sekolah-sekolah yang kemudian kegiatan tersebut kemudian juga dipamerkan lagi di indtagram, sebagai berikut:

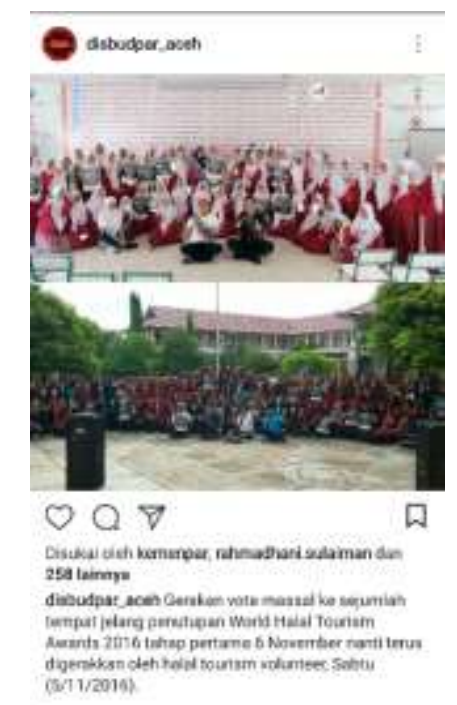

Gambar: kampanye vote Aceh di sekolah

\section{TAHAP KONFIRMASI}

Akhirnya, dengan beragam upaya yang telah dilakukan di tahun yang sama, Aceh memenangkan dua kategori pada World Halal Tourism Award 2016. Indonesia memenagkan 12 kategori dari 16 kategori yang dipertarungkan. Dari 12 kategori, Aceh memenangkan dua kategori untuk keikutsertaannya pertama kali pada ajang tersebut yaitu sebagai world's best airport for halal travellers dan world's best cultural destination. 


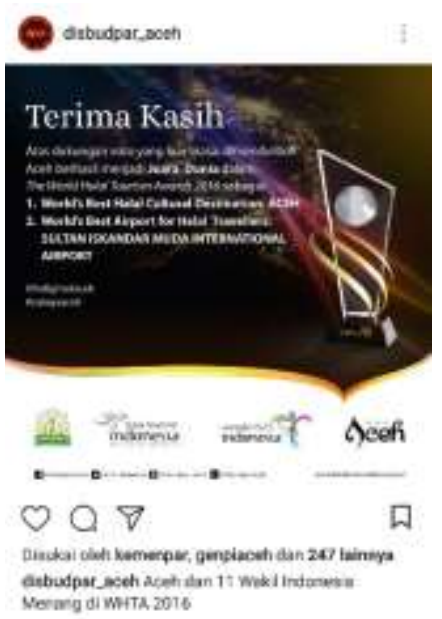

Gambar: World Halal Tourism Award 2016

Selain memenangkan kompetisi, beberapa komunitas serta masyarakat umumpun mengadopsi alphabet logo pariwisata Aceh pada logonya. Menurut komunitas Skuter Aceh yang juga mengadopsi logo ini, hal ini dimaksudkan agar langsung identik dan menunjukkan identitas keAcehan. Hal ini menunjukkan bahwa brand tersebut mudah diterima oleh masyarakat internal Aceh sendiri.

\section{KESIMPULAN}

Upaya yang dijalankan oleh disbudpar Aceh dalam mengkonstruksi destinasi wisata halal aceh dengan memanfaatkan social media terutama Instagram sangat tepat. Mengingat data APJI 2017 pengguna internet tertinggi berusia 19-34 tahun sebanyak 49,52\%. Menggandeng komunitas anak muda untuk terlibat dalam kampanye voting KPHN dan WHTA pada tahun 2016 telah terbukti keberhasilannya. Namun, bertolak belakang dengan identitas pariwisata yang dibentuk, Aceh masih dianggap tidak aman oleh banyak pihak internasional. Bukan karena konflik yang berkepanjangan dimasa lalu. Namun karena pemberitaan media terkait pelaksanaan syariah islam. Sebagai contoh, perhelatan Aceh internasional marathon yang akan diselenggarakan 29 juli tahun 2018 di kota Sabang yang awalnya diprediksi akan diikuti oleh 4000 pelari dengan tujuan untuk mempromosikan keramahan, suasana aman serta terbukanya aceh bagi wisatawan dan investasi, namun masih kurang diminati karena Aceh dianggap kurang aman (kompas.com, februari 2018) salah satunya karena isu penolakan 
terhadap Lesbian Gay Biseksual dan Transgender (LGBT) di Aceh dan anggapan bahwa untuk pelari perempuan diwajibkan berjilbab. Hal ini beriringan pula dengan himbauan dari bupati Aceh Besar yang mewajibkan pramugari memakai jilbab ketika berada di bandara sultan Iskandar muda, Aceh Besar. Masih banyak tantangan yang harus dihadapi oleh Aceh untuk mengkonstruksi identitas pariwisatanya sebagai cahaya, sebagai rahmatan lil alamin. Namun upaya yang telah dilakukanpun memberikan hasil meskipun masih membutuhkan waktu agar benar-benar tertanam di benak dan dipercayai oleh publik. Untuk pengembangannya, mendapatkan dukungan penuh dari masyarakat dan para stakeholders selayaknya harus menjadi prioritas dengan melakukan pendekatan persuasif secara bertahap. Mengembangkan opini bahwa pariwisata tidak bertentangan dengan nilai Islam asal seluruh komponen masyarakat melakukan pengawasan dan pihak berwenang membuat standar kebijakan yang dapat diterima oleh seluruh komponen termasuk pihak swasta, ulama, umara dan masyarakat. Keterlibatan masyarakat di seluruh provinsi harus menjadi prioritas dengan melakukan pendekatan secara massif oleh para opinion leaders. Untuk mendapatkan dukungan dari media massa konvensional, tentu saja pemerintah harus mengubah cara kerjanya dengan mengutamakan kepentingan publik. Perbaikan, penyediaan, pengelolaan serta pemanfaatan sarana dan prasarana publik untuk kepentingan publik serta mengukir banyak prestasi yang diakui oleh beragam Lembaga, tentu akan menciptakan berita dengan tone positif pada media massa meski tak dapat dipungkiri bahwa bad news tentu lebih menarik untuk dimuat. Namun beragam prestasi tersebut dapat mengimbangi berita dengan tone negatif meski tak mungkin untuk dihindari. Yang lebih sederhana dan mudah serta menjangkau publik yang lebih luas adalah memanfaatkan sosial media dan bekerjasama dengan komunitas milenials. Hal ini sudah dibuktikan oleh Dinas Kebudayaan dan Pariwisata Aceh hingga mampu memenangkan kompetisi pariwisata internasional serta mendapatkan penghargaan kehumasan. Tak hanya pemerintah provinsi, kesadaran dan kerjasama dengan stakeholders kabupaten/kota tentu akan semakin memperkuat brand pariwisata halal Aceh. Wisata halal Aceh merupakan sebuah komoditi. Menjual nilai-nilai kearifan lokal 
dalam bentuk pariwisata. Sekaligus sebagai bentuk syiar yang menyesuaikan tuntutan jaman. Tema wisata halal merupakan marketing daerah untuk menjadi daerah tujuan wisata. Wisata halal sebagai bentuk positioning Aceh sebagai destinasi yang unik. Budaya halal harus terlebih dahulu menjadi kepribadian masyarakat Aceh. Halal itu tidak hanya soal makanan. Tetapi juga perilaku, kepribadian, kebersihan, hospitality, kesopanan, dan lain sebagainya. Apabila semua itu terwujud, maka dengan sendirinya pariwisata halal akan bergerak menciptakan kebaikan bagi masyarakat juga bagi wisatawan. 


\section{DAFTAR PUSTAKA}

Bungin, Burhan. (2008). Konstruksi Sosial Media Massa: Kekuatan Pengaruh Media Massa, Iklan Televisi dan Keputusan Konsumen serta Kritik terhadap Peter L. Berger \& Thomas Luckmann. Jakarta: Kencana.

Flew, Terry. (2008). New Media: An Introduction. Oxford University Press.

Hasan, Ali. (2015). Tourism Marketing. Yogyakarta: CAPS.

Koswara, Aang. (2013).City’s Branding ala Munich. Bandung: Rosda.

McQuail, Denis (2011). Teori Komunikasi Massa. Jakarta: Salemba Humanika.

Nadlir, Moh. (2018). Gara-gara Isu LGBT, Aceh International Marathon 2018 Sepi Pendaftar. https://nasional.kompas.com/read/2018/02/13/19113441/gara-gara-isulgbt-aceh-international-marathon-2018-sepi-pendaftar

Patton, M. (2002). Qualitative Research and Evaluation Methods, Third Edition, CA: Sage.

Suryatna, Asep. (2019) Komunikasi Pemasaran. Banten: Universitas Terbuka. 